\title{
How does soil pollution risk perception affect farmers' pro-environmental behaviour? The role of income level
}

\author{
Zhifang Zhou \\ School of Business, Central South University \\ Jinhao Liu \\ School of Business, Central South University \\ Huixiang Zeng \\ School of Business, Central South University \\ Tao Zhang* \\ Institute for Innovation and Entrepreneurship, Loughborough University London \\ Xiaohong Chen \\ School of Business, Central South University
}

*Corresponding author's email: T.N.Zhang @lboro.ac.uk 


\title{
How does soil pollution risk perception affect farmers' pro-environmental behavior? The role of income level
}

\begin{abstract}
Soil pollution is a serious environmental issue in China. As a key subject of agricultural practices, promoting Chinese farmers' Pro-Environmental Behavior (PEB) through increasing their soil pollution risk perception is an important means for soil protection, agricultural transformation and ecological development. In this study, we distinguish four dimensions of soil pollution risk perception: fact perception (FP), loss perception (LP), cause perception (CP) and response behavior ability perception (RBAP). We conceptualize a model that depicts the relationships between the four dimensions of Chinese farmers' soil pollution risk perception and their PEB and the moderating effect of farms' household income level on these relationships. Using a questionnaire survey to collect empirical data, we find: first, the four dimensions of Chinese farmers' soil pollution risk perception have positive effects on their PEB; second, Chinese farmers' household income level positively moderates the relationships between their FP, LP and CP and their PEB but its moderating effect on the relationship between their RBAP and their PEB is not significant. Relevant theory and policy implications for environmental management are discussed in the paper.
\end{abstract}

Keywords: Soil pollution; Risk perception; Income level; Pro-environmental behavior

\section{Introduction}

Soil is the foundation of human development, and the utilization and protection of soil resources are closely related to human welfare. However, with the rapid growth of China's economy, soil pollution has become an increasingly prominent problem that has seriously affected the biodiversity of China's soil ecosystem and the safety of the country's food supply chain (Chen et al., 2014; Delang, 2017; Hou and Li, 2017). According to the National Soil Pollution Status Survey Bulletin, the level of pollution of China's cultivated land has exceeded the standard rate of $19.4 \%^{1}$, and the size of

${ }^{1}$ Soil Environmental Quality Standards-GB15618-1995 
polluted cultivated land has reached 10 million hectares. The total annual agricultural economic loss caused by soil pollution is about 20 billion US dollars (Yang et al., 2018). The unsustainable use of chemical fertilizers and pesticides is the main cause of soil pollution (Chen et al., 2014). Faced with such a severe soil pollution situation, the Chinese government has successively issued a series of soil protection policies, such as the Soil Pollution Prevention Action Plan and the Soil Pollution Prevention and Control Law. These measures place stringent requirements on soil pollution prevention and control. Farmer behavior - the main element in agricultural practices is directly related to soil quality. However, due to the lack of environmental protection awareness and the aggravation of income pressure, Chinese farmers have increased the use of chemical fertilizers, pesticides, plastic films and other chemicals to improve production efficiency, which aggravates the problem of soil pollution (Yang et al., 2018; Sun, Hu, et al., 2019; Sun, Li, et al., 2019). Because agriculture is a significantly important economic sector in China (Qi et al., 2018), and greening is the inevitable trend of future agricultural development, many scholars have been vigorously researching on an effective approach to promote farmers' pro-environmental behavior (PEB) and support a transformation of agricultural ecology and green development (Shiva, 2016; Struik and Kuyper, 2017).

A farmer's PEB can be regarded as the activities that the farmer is engaged in to protect the agricultural environment during agricultural production process, such as reducing the use of chemical fertilizers and plastic films and/or avoiding straw burning, etc. (Bell et al., 2016). This behavior is affected by many factors, e.g. farmers' education level, attitude, subjective norms, governments' environmental regulations, etc. (Marr and Howley, 2019; Wang et al., 2019). Although extant research has given us some understanding of the factors that can influence farmers' PEB, farmers' perception of soil pollution and the psychological mechanisms behind the influence farmers' perception of soil pollution on their PEB have not been explored. This paper seeks to address this gap in the literature. Based on the Protection Motivation Theory (PMT), we develop the concept of farmers' soil pollution risk perception and then explore the relationship between farmers' soil 
pollution risk perception and their PEB.

Additionally, considering the specific Chinese setting, we examine the moderating effect of farmers' income level on the relationship. The rationale for involving farmers' income level as a moderation factor is that, compared with agricultural workers in developed countries, Chinese farmers are more dependent on farming incomes which have significant influence on their PEB. For example, in the EU member states, an agri-environment scheme (AES) has been implemented through contracts between public institutions and various beneficiaries (farmers or land managers). This scheme requires EU farmers to change their farming practices in return for compensation per hectare of land, thus providing direct subsidies or price support for agriculture and encouraging EU farmers to engage in environmentally friendly farming practices (e.g. organic farming) that protect arable lands and wetlands (Lastra-Bravo et al., 2015; Mills et al., 2017). The scheme also promotes the change of the rural industrial structure and the expansion of agricultural activities and generates a wide range of discretionary funds which help to reduce EU farmers' dependence on farming income, thereby reducing the risk of income loss (Barreiro-Hurlé et al., 2010; Lastra-Bravo et al., 2015; Morris et al., 2017). However, in China, the economic and policy environment is very different. Although the income of Chinese farmers has improved since the reform of the "household contract responsibility system", Chinese farmers' dependence on farming income from farmlands is still very high. To improve their economic interests, Chinese farmers often tend to abuse their farmlands, causing great damage to the ecosystem ( $\mathrm{Wu}$ and Ge, 2019; Xu et al., 2017). Therefore, it is important to examine how the level of household income of Chinese farmers affects the relationship between their soil pollution risk perception and their PEB.

The remainder of this paper is organized as follows. Section 2 reviews prior literature and develops research hypotheses. Section 3 introduces our research design. Section 4 presents the empirical analysis and results. Section 5 discusses the research findings, and Section 6 concludes the study.

\section{Theoretical background and hypotheses}




\subsection{Pro-environmental Behavior}

Pro-environmental behavior (PEB) is defined as "the intentional act of protecting the environment" (Stern, 2000). It usually includes both workplace and non-workplace elements (Azhar and Yang, 2019; Vicente-Molina et al., 2018). The workplace PEB refers to employees' voluntary participation in environment-friendly activities that are encouraged but not enforced by the organization (Steg and Vlek, 2009). Employees' work place PEB has attracted significant research attention in business and public studies (Azhar and Yang, 2019; Paillé et al., 2016; Tian and Robertson, 2019). Non-workplace PEB comprises individuals' behavior outside workplaces that attempts to reduce negative environment impact or is conducive to the environment, and research in non-workplace PEB often focuses on family or individual levels (Collado et al., 2019; Han, 2015a). PEB is mainly affected by two factors: economic drive and moral drive (Azhar and Yang, 2019; Farrow et al., 2017; Schmitt et al., 2018). Economic drives generally occur when individuals realize that PEB has an economic impact on their personal interests. They will personally decide whether to engage in PEB, e.g. consuming less, purchasing energy-saving products, optimizing garbage collection, etc. (Lange and Dewitte, 2019; Zhao et al., 2019). Moral drives generally occur when an individual's professional ethics or social conscience affects his or her PEB (Meyer, 2015). Additionally, PEB is also affected by many individual variables such as gender and personality traits (Vicente-Molina et al., 2018).

\subsection{Soil pollution risk perception and PEB}

Risk perception describes people's subjective judgments about hazardous activities and technologies (Slovic, 1987). Researchers use this concept to explain how risk is perceived, how much harm is expected to be caused to the public, and how risk loss can be reduced (Renn, 2017). Risk perception can be quantified and predicted, and it is influenced by psychological, socio-economic and cultural processes, including individual and collective cognitive processes as well as risk communications (Marcon et al., 2015; Slovic, 1987; Sullivan-Wiley and Gianotti, 2017). Environmental risk is a special risk. It is different from other types of risks (e.g. 
natural risks), and is closely related to how people are concerned about environmental problems (Götz et al., 2019). Believing that the natural environment is endangered by humans, and that there is a will to protect the nature given a high degree of uncertainty, severity of consequences and delay, are an individual's direct perception (Franzen and Vogl, 2013; Gattig and Hendrickx, 2007). According to environmental psychology, environmental perception is developed based on an individual's interaction with the environment. Soil pollution risk perception is reflected by people's values and attitudes toward the environment (De Groot, 2018; Grasmück and Scholz, 2005). For farmers, it is the process of identifying the surrounding soil pollution caused by farming (Liu et al., 2018; Vandermoere, 2008). Therefore, the extent to which farmers are connected to local soil pollution problems plays an important role in their understanding of risks and making judgments (Weber et al., 2001).

Integrating Protection Motivation Theory (PMT) and risk perception can explain farmers' PEB. PMT was originally used to explain how people choose to protect themselves (Maddux and Rogers, 1983; Rogers, 1975), and then gradually became a popular theory to explain how people reduce natural disasters and environmental risks (Bubeck et al., 2018; Mertens et al., 2018). PMT believes that people take adaptive actions through two major cognitive processes: threat assessment and response assessment (Boss et al., 2015). Threat assessment is a cognitive process through which an individual estimates the degree of threat, while coping assessment is an individual's assessment of his/her ability to perform risk prevention behavior (Boss et al., 2015; Maddux and Rogers, 1983; Mertens et al., 2018; Rogers, 1975). Environmental risks cause problems for people and often lead to people's preventive responses (Estévez et al., 2015; Smith and Mayer, 2018). People's personal values and beliefs explain how they view risks and evaluate potential hazards, thus affecting their personal attitudes and behavior (Smith and Mayer, 2018). When people are aware of environmental risks and pay attention to these risks, they are more likely to care about the mitigation of environmental problems and the improvement of environmental quality, and they are more willing to act pro-environmentally. Therefore, the perception of environmental problems affects environmental 
behavior (Lacroix and Gifford, 2018; Slovic, 2016). For example, with regard to air pollution, residents avoid outdoor activities and even use facial masks at home to protect themselves from air pollution (Jia, 2018).

According to PMT, farmers perceive threats from soil pollution caused by their agricultural activities. When facing environmental risks, threats perceived by farmers may prompt them to participate in PEB to reduce these risks (Bockarjova and Steg, 2014; Janmaimool, 2017; Kim et al., 2013). Farmers in the process of agricultural production use significant amounts of pesticides, chemical fertilizers and plastic films to improve their production efficiency and economic benefits. However, these chemicals contain certain elements (e.g. $\mathrm{Hg}, \mathrm{Cd}, \mathrm{Pb}, \mathrm{As}$ and other bio-toxic elements) that can seep into the surrounding soil, water and air, causing a significant threat to the environment (Delang, 2017; Özkara et al., 2016; Singh et al., 2019). Several epidemiological studies in recent years have shown the effects of soil pollution on human health, including possible links with glioma, leukemia and cancer (Filis et al., 2019; Gunier et al., 2017; Van Maele-Fabry et al., 2017). The use of organochlorine pesticides and phosphate fertilizers has been restricted in many countries (Diendéré et al., 2018; Sankoh et al., 2016). When considering the possible risks of soil pollution caused by agricultural activities (e.g. using organochlorine pesticides, phosphate fertilizers, mulch, etc.), farmers will have a sense of risk that can affect their agricultural practices, and they will be more willing to take measures to reduce risks and protect themselves (Lu et al., 2015; Thompson, 2017).

Coping assessment is the assessment of farmers' ability to cope with the risk of soil pollution, i.e., farmers' perceptions of whether their actions can avoid or reduce threats. Coping assessment usually includes self-efficacy perception, response effectiveness perception and protection action cost perception (Bockarjova and Steg, 2014). Self-efficacy refers to whether a farmer believes that he or she can take protective measures or actions to protect the soil, while response efficacy refers to whether the farmer believes that taking protective measures will effectively reduce the risk of soil pollution. Cost perception refers to the farmer's perception of all costs related to soil protection measures or actions, including monetary and non-monetary 
costs (Kim et al., 2013). Therefore, in terms of coping assessment, high self-efficacy perception and response efficacy perception and low-cost perception have positive effects on farmers' PEB.

Risk has multiple dimensions, including risk results, exposure degree, risk hazards and risk losses. Risk perception is the process of finding and describing risk events, risk sources and risk consequences (Marcon et al., 2015; Slovic, 1987). Risk perception can be measured from different dimensions of risk. Two popular ways of risk perception measurements are the two-dimensional view of "worry degree" and "unknown risk" proposed by Slovic (1987), and the dynamic multi-dimensional risk perception model (Langford et al., 1999). We consider the multi-dimensional characteristics of soil pollution risk (Bockarjova and Steg, 2014; Grasmück and Scholz, 2005; Liu et al., 2018; Weber et al., 2001). Based on the two main cognitive processes of "threat assessment" and "cognitive assessment" in PMT, and the two-dimensional view of Slovic (Boss et al., 2015; Slovic, 1987), we divide farmers' soil pollution risk perceptions into four dimensions: risk fact perception, risk loss perception, risk cause perception and risk response behavior ability perception. In the light of the above discussions, we propose the following hypotheses:

Hypothesis 1a: Farmers' risk fact perception of soil pollution positively affects their pro-environment behavior

Hypothesis 1b: Farmers' risk loss perception of soil pollution positively affects their pro-environment behavior

Hypothesis 1c: Farmers' risk cause perception of soil pollution positively affects their pro-environmental behavior

Hypothesis 1d: Farmers' risk response behavior ability perception of soil pollution positively affects their pro-environmental behavior

\subsection{Household income level}

The theory of reasoned action (TRA) was first proposed by Ajzen (1980) and was later widely used to explain personal pro-environment behavior (Kim et al., 2013; Paço and Lavrador, 2017; Sun et al., 2018). TRA is based on the assumption that a person is rational and synthesizes information to consider the meaning and 
consequences of his or her actions (Ajzen and Fishbein, 1980). According to TRA, a person's intention to act in a certain way is based primarily on two factors: the "attitude" (the feeling of being inclined or considered) to a particular action and the individual's perception of social pressure for him or her to act in a certain way (Rehman et al., 2007). Research shows that the relationship between behavioral intention and behavior is stable, but only moderately strong. Due to the influence of some moderating variables, individuals' strong behavioral intentions may not be transformed into actual behaviors (Armitage and Conner, 2001; Hagger et al., 2002; Han, 2015b; Orbell et al., 1997). Therefore, while farmers are making environment-friendly agricultural decisions, they are subject to a series of social conditions, including economic factors (Lo, 2014; Toma and Mathijs, 2007), policy background (Malawska and Topping, 2016) and family background (Aydogdu and Yenigün, 2016; Wachinger et al., 2013). Economic factors generally play a decisive role, ultimately leading to or limiting farmers' ability to protect the environment (Toma and Mathijs, 2007). At higher levels of income, individuals have higher demand for quality of life, so they tend to be risk averse and are willing to pay more to mitigate risk (Berthe and Elie, 2015; Jorgenson et al., 2017). Thus, risk awareness should increase with the increase of personal and family incomes. In the process of perceiving the risk of soil pollution, farmers are affected by their income levels and will pay different levels of attention to the surrounding environment, which affects their perception of the risk of soil pollution (Lo, 2014). In addition, combined with the cognitive process of "coping assessment" articulated in PMT (Boss et al., 2015), when the income levels of farmers increase, their economic and technical ability will be enhanced, and their environmental protection intention will be more likely to be realized. Therefore, their ability to cope with risks will be enhanced (Huang et al., 2017; Morren and Grinstein, 2016), which will significantly affect their risk perception regarding soil pollution.

According to the Environmental Kuznets Curve (EKC), pollution increases with the increase of per capita GDP at low income levels and decreases with the increase of per capita GDP at high income levels (Grossman and Krueger, 1991, 1995). This 
theory is based only on the level of regional economic development or macro level income, and it cannot explain the strong environmental concerns of people in developing countries from individual or micro level incomes (Katz, 2015; Ponce et al., 2019; Shao, Tian and Fan, 2018; Sun and Zhu, 2014). However, EKC suggests that low-income residents pay more attention to their current and future living environment after their income level increases, which triggers their demand for higher environmental quality and more robust PEB (Dinda, 2004; Shao et al., 2018). As a developing country, China's income per household is at a relatively low level, but its residents show strong environmental awareness (Li et al., 2012). Therefore, China is an interesting empirical setting to introduce household income level of farmers as a moderating variable at the micro level.

Post-materialism theory points out that good environment is considered by materialists to be quality of life, and environmental preferences must meet the basic material needs (Inglehart, 2018). This viewpoint is related to Maslow's hierarchical demand theory. Driven by life pressures, farmers often adjust their farming practices to gain economic benefits at the expense of the quality of land ecosystems (Abulizi et al., 2017). From the perspective of the direct effects of income, the affluence hypothesis believes that the environment is a normal commodity, the demand for which increases with income. In richer countries or regions, citizens tend to have more pro-environment behavior (Franzen, 2003). Therefore, in a low-income society, even though farmers perceive the risks of soil pollution, they are unwilling to adopt PEB. However, when their income levels increase, farmers will pay more attention to soil pollution, which will affect their PEB. Based on the above analysis, we propose the following hypotheses:

Hypothesis 2a: Farmers' household income level positively moderates the relationship between farmers' risk fact perception of soil pollution and their pro-environment behavior

Hypothesis 2b: Farmers' household income level positively moderates the relationship between farmers' risk loss perception of soil pollution and their pro-environment behavior 
Hypothesis 2c: Farmers' household income level positively moderates the relationship between farmers' risk cause perception of soil pollution and their pro-environment behavior

Hypothesis 2d: Farmers' household income level positively moderates the relationship between farmers' risk response behavior ability perception of soil pollution and their pro-environment behavior

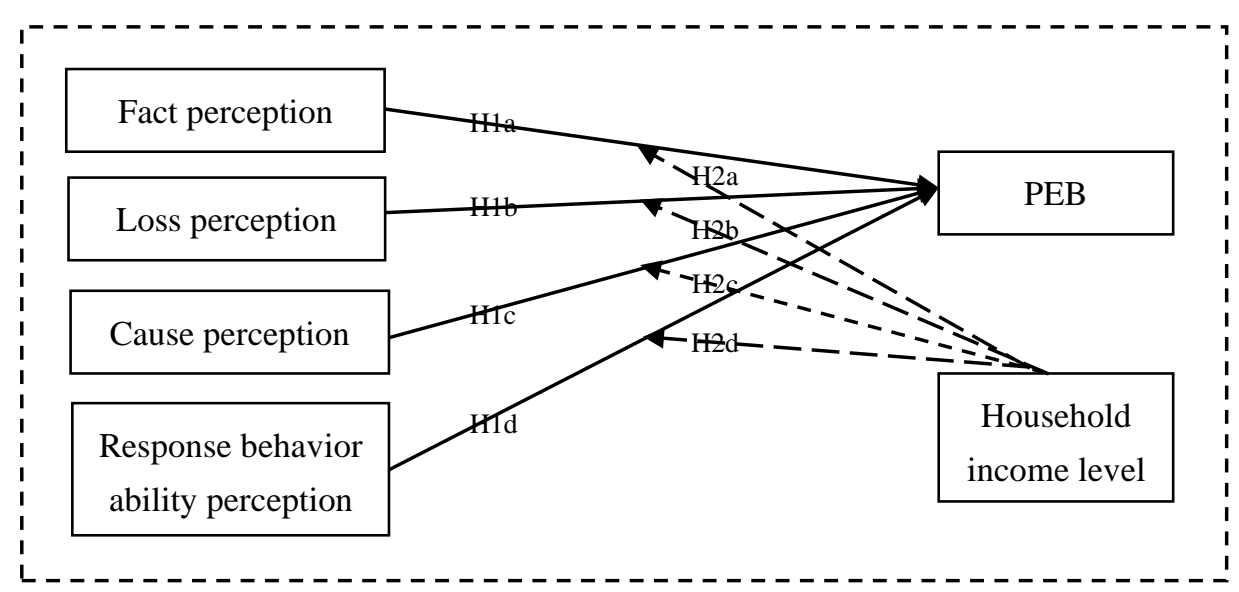

Figure 1. Conceptual model

\section{Research design}

\subsection{Variable measurement}

(1) Environmental risk perception measurement

Based on Grasmück et al. (2005), Vandermoere et al. (2008), Frondel et al. (2017) and other studies, we designed 14 items. According to farmers' feelings about these 14 items, we measured farmers' soil pollution risk perception degree. We used a five-point Likert scale to score each item. The specific content is shown in Table 2.

(2) Farmers' environmental behavior measurement

It is measured according to the three major types of farmers' behavior that pollutes the soil (use of pesticides, fertilizers, and plastic film). The items of PEB are: "Reducing the use of organochlorine pesticides in the subsequent agricultural production"; "Reducing the use of phosphate fertilizer in the subsequent agricultural production"; and "Reducing the use of plastic film in the subsequent agricultural production". We used a five-point Likert scale to score each item. The specific content is shown in Table 2 . 
(3) Measurement of farmers' household income level

This variable is measured using the per capita annual income of a household last year.

(4) Control variables

According to prior literature (Diendéré et al., 2018; Melo et al., 2018; Meyer, 2015; Vicente-Molina et al., 2018), gender, age, education level, family population and per capita production scale all have certain impacts on PEB. Therefore, these variables are treated as control variables in our research. The specific content is shown in Table 1.

\subsection{Data collection}

In order to directly and objectively reflect the real situation of farmers' risk perception of soil pollution, we conducted field research through a questionnaire survey using random sampling. The research subjects were local farmers, and the research period was May to July 2019. The selection of survey sites was based on the regional characteristics of Hunan Province and the distribution of soil pollution in China. Hunan Province is located in central southern China and the middle reaches of the Yangtze River. It is a traditional agricultural province. Since ancient times, it has been known as "The Granary of Jiuzhou" and "The Land of Fish and Rice". The province's rice planting area and yield are always the highest in China. Soil pollution in Hunan Province has become very serious in recent years, and a wide range soil pollution accidents have occurred (Zhang et al., 2019), Therefore, we chose Hunan Province as our research site. In addition, considering the differences in regional economic development, Changsha (the capital and also the most developed region of Hunan Province) and the Xiangxi Tujia and Miao Autonomous Prefecture (a key area for poverty alleviation in China) were selected as research sites; and Changsha, Ningxiang, Fenghuang and Guzhang were further selected as specific research sites. To ensure the accuracy and representativeness of the samples, 30 families were randomly selected from each village, and one questionnaire was distributed to each family. To prevent political sensitivities from affecting the research, ordinary villagers (not village cadre members) were chosen as the respondents. A total of 1,500 
questionnaires were distributed throughout the survey. After face-to-face interviews, 1388 questionnaires were collected, among which 1247 were valid, for an effective recovery rate of $82.86 \%$.

The no-response bias test can test whether the individual's participation in the survey leads to differences in understanding the problem and/or can verify whether the findings are generalizable. In this study, according to Chen (2004), the questionnaire was divided into three parts, and the difference between the first third and the last third was tested using Chi-square test. The results were not significantly different. Therefore, the data obtained in our study has no significant response bias and can be used for empirical research.

Table 1. Sample characteristics

\begin{tabular}{|c|c|c|c|c|c|c|c|}
\hline Category & Mark & Number & $\begin{array}{c}\text { Proportion } \\
(\%)\end{array}$ & Category & Mark & Number & $\begin{array}{c}\text { Proportion } \\
(\%)\end{array}$ \\
\hline \multicolumn{4}{|c|}{ Gender } & \multicolumn{4}{|c|}{ Education level } \\
\hline Male & 1 & 956 & $76.7 \%$ & $\begin{array}{c}\text { Below } \\
\text { elementary } \\
\text { school }\end{array}$ & 1 & 159 & $12.8 \%$ \\
\hline Female & 2 & 291 & $23.3 \%$ & $\begin{array}{c}\text { Elementary } \\
\text { school }\end{array}$ & 2 & 527 & $42.3 \%$ \\
\hline \multicolumn{4}{|c|}{ Age } & $\begin{array}{c}\text { Middle } \\
\text { school }\end{array}$ & 3 & 342 & $27.4 \%$ \\
\hline $\begin{array}{c}30 \text { years } \\
\text { old and } \\
\text { below }\end{array}$ & 1 & 84 & $6.7 \%$ & $\begin{array}{c}\text { High } \\
\text { school }\end{array}$ & 4 & 156 & $12.5 \%$ \\
\hline $\begin{array}{c}30 \sim 45 \\
\text { years old }\end{array}$ & 2 & 313 & $25.1 \%$ & $\begin{array}{c}\text { Bachelor } \\
\text { degree or } \\
\text { above }\end{array}$ & 5 & 63 & $5 \%$ \\
\hline $\begin{array}{c}30 \sim 45 \\
\text { years old }\end{array}$ & 3 & 607 & $48.7 \%$ & \multicolumn{4}{|c|}{ Family per capita production scale } \\
\hline $\begin{array}{l}60 \text { years } \\
\text { old or } \\
\text { above }\end{array}$ & 4 & 243 & $19.5 \%$ & $\begin{array}{c}2 \text { acres and } \\
\text { below }\end{array}$ & 1 & 647 & $51.9 \%$ \\
\hline \multicolumn{4}{|c|}{ Family population } & $2 \sim 3$ acres & 2 & 254 & $20.4 \%$ \\
\hline $\begin{array}{l}3 \text { and } \\
\text { below }\end{array}$ & 1 & 48 & $3.8 \%$ & $3 \sim 4$ acres & 3 & 175 & $14 \%$ \\
\hline 4 & 2 & 222 & $17.8 \%$ & $\begin{array}{c}4 \text { acres or } \\
\text { above }\end{array}$ & 4 & 171 & $13.7 \%$ \\
\hline 5 & 3 & 552 & $44.3 \%$ & & & & \\
\hline
\end{tabular}




\begin{tabular}{|l|l|l|l|}
\hline 6 or above & 4 & 425 & $34.1 \%$ \\
\hline
\end{tabular}

\subsection{Reliability and validity}

(1) Reliability test

Reliability is an important measure of the consistency and stability of the questionnaire design. We used Cronbach's Alpha coefficient to determine the scale reliability, and we adopted SPSS22.0 to test the reliability of each dimension of soil pollution risk and PEB. As shown in Table 2, Cronbach's Alpha coefficients for each dimension of soil pollution risk perception and PEB were 0.919, 0.871, 0.915, 0.945 and 0.896 , and all of them were greater than 0.8 , indicating that the scale used in the study had good reliability. In addition, in terms of internal consistency, the combined reliability (SCR) of all dimensions of the scale was above 0.7. Therefore, the scales used in this study are reliable.

Table 2. Reliability and validity tests of the scales

\begin{tabular}{|c|c|c|c|c|}
\hline Dimension & Item description & $\begin{array}{l}\text { Factor } \\
\text { loading }\end{array}$ & $\mathrm{CR}$ & AVE \\
\hline \multirow{4}{*}{$\begin{array}{l}\text { Fact perception } \\
\qquad(\mathrm{FP}) \alpha=0.919\end{array}$} & You know something about soil & 0.802 & \multirow{4}{*}{0.9187} & \multirow{4}{*}{0.7392} \\
\hline & $\begin{array}{l}\text { You know more about soil pollution } \\
\text { than other villagers }\end{array}$ & 0.830 & & \\
\hline & $\begin{array}{l}\text { You are concerned about soil } \\
\text { pollution }\end{array}$ & 0.925 & & \\
\hline & You want to reduce soil pollution & 0.877 & & \\
\hline \multirow{4}{*}{$\begin{array}{l}\text { Loss perception } \\
\qquad(\mathrm{LP}) \alpha=0.871\end{array}$} & Soil pollution effects your health & 0.863 & \multirow{4}{*}{0.8751} & \multirow{4}{*}{0.6403} \\
\hline & Soil pollution affects your offspring & 0.892 & & \\
\hline & $\begin{array}{l}\text { Soil should be protected as a living } \\
\text { part of our environment }\end{array}$ & 0.789 & & \\
\hline & $\begin{array}{l}\text { Soil as a living part of our } \\
\text { environment should be protected }\end{array}$ & 0.631 & & \\
\hline \multirow{3}{*}{$\begin{array}{l}\text { Cause perception } \\
\qquad(\mathrm{CP}) \alpha=0.915\end{array}$} & $\begin{array}{l}\text { The use of organochlorine pesticides } \\
\text { may contaminate the soil }\end{array}$ & 0.864 & \multirow{3}{*}{0.9166} & \multirow{3}{*}{0.7858} \\
\hline & $\begin{array}{l}\text { The use of phosphate fertilizer may } \\
\text { contaminate the soil }\end{array}$ & 0.855 & & \\
\hline & $\begin{array}{l}\text { The use of plastic film may } \\
\text { contaminate the soil }\end{array}$ & 0.938 & & \\
\hline $\begin{array}{c}\text { Response } \\
\text { behavior ability }\end{array}$ & $\begin{array}{l}\text { You can take soil conservation } \\
\text { measures or actions }\end{array}$ & 0.911 & 0.9463 & 0.8546 \\
\hline
\end{tabular}




\begin{tabular}{|c|c|c|c|c|}
\hline \multirow[t]{2}{*}{$\begin{array}{c}\text { perception } \\
(\text { RBAP) } \alpha=0.945\end{array}$} & $\begin{array}{l}\text { Conservation measures will actually } \\
\text { reduce the risk of soil pollution } \\
\text { The cost of protecting the soil is } \\
\text { acceptable }\end{array}$ & 0.920 & & \\
\hline & $\begin{array}{l}\text { you will reduce the use of } \\
\text { organochlorine pesticides in the } \\
\text { following agricultural production }\end{array}$ & 0.850 & & \\
\hline $\begin{array}{c}\text { Pro-environmental } \\
\text { behavior } \\
(\mathrm{PEB}) \alpha=0.896\end{array}$ & $\begin{array}{l}\text { You will reduce the use of phosphate } \\
\text { fertilizer in the following agricultural } \\
\text { production }\end{array}$ & 0.925 & 0.9259 & 0.7582 \\
\hline & $\begin{array}{l}\text { You will reduce the use of plastic } \\
\text { film in the following agricultural } \\
\text { production }\end{array}$ & 0.780 & & \\
\hline
\end{tabular}

(2) Validity test

The internal validity of the scale can be measured from three aspects: content validity, convergent validity, and discriminative validity. In terms of content validity, most of the items in the scales are well established ones adopted from prior studies. We also invited experts in agricultural and forestry economic management and environmental protection to conduct semi-structured interviews, and we revised some items to ensure the content validity of the scale. In terms of convergence validity, we used AMOS17.0 for the factor analysis of the items of each dimension. The specific results are shown in Table 2. The factor loadings of all items were between 0.631 and 0.942, significant at the 0.001 level. Therefore, the scales have good convergence validity. In terms of discriminant validity, we used SPSS22.0 to analyze the correlation of variables. The specific results are shown in Table 3. The average extraction variation AVE square root of soil pollution risk fact perception, loss perception, response behavior ability perception and PEB values are 0.8597, 0.8001, $0.8865,0.9244$ and 0.8707 . These numbers are clearly larger than the respective correlation coefficients in Table 3, which further indicates that each dimension has good discriminant validity.

\section{Data analysis and hypothesis testing}

\subsection{Correlation analysis}


In order to identify whether there is multicollinearity between variables, we conducted Pearson (lower triangle) correlation analysis on the main variables, and the correlation coefficient matrix of each variable is shown in Table 3. The results of this correlation coefficient analysis show that there is significant positive correlation between both gender and education level with fact perception, loss perception, cause perception, response behavior ability perception of soil pollution risk and PEB (P < 0.05). Interestingly, there is a negative correlation between age and PEB, which is contrary to the finding of Meyer et al. (2015). We discuss this finding further later in this paper via a regression model.

It can be seen from Table 3 that there is a significant positive correlation between fact perception, loss perception, cause perception and response behavior ability perception of soil pollution risk with PEB $(\mathrm{P}<0.05)$. Hypotheses $1 \mathrm{a}, 1 \mathrm{~b}, 1 \mathrm{c}$ and $1 \mathrm{~d}$ are preliminarily supported. We can see that the maximum absolute values of the correlation coefficients among the variables of household income level, fact perception, loss perception, cause perception, response behavior ability perception and PEB are all less than 0.8 , indicating that there is no multicollinearity. 
Table 3. Correlation matrix

\begin{tabular}{|c|c|c|c|c|c|c|c|c|c|c|}
\hline & Gender & Age & Education & $\begin{array}{c}\text { Family } \\
\text { per capita } \\
\text { production } \\
\text { scale }\end{array}$ & $\begin{array}{c}\text { Family } \\
\text { population }\end{array}$ & HIL & FP & LP & $\mathrm{CP}$ & RBAP PEB \\
\hline Gender & 1.000 & & & & & & & & & \\
\hline Age & $-0.284 * *$ & 1.000 & & & & & & & & \\
\hline Education & $0.195 * *$ & $-0.665 * *$ & 1.000 & & & & & & & \\
\hline Household per capita production scale & 0.001 & -0.011 & 0.031 & 1.000 & & & & & & \\
\hline Family population & $-0.144 *$ & $0.578 * *$ & $-0.394 * *$ & $0.120 *$ & 1.000 & & & & & \\
\hline Household income level (HIL) & $0.287 * *$ & $-0.331 * *$ & $0.300 * *$ & -0.085 & $-0.252 * *$ & 1.000 & & & & \\
\hline Fact perception (FP) & $0.193 * *$ & $-0.339 * *$ & $0.332 * *$ & -0.014 & $-0.270 * *$ & $0.282 * *$ & 1.000 & & & \\
\hline Loss perception (LP) & $0.256 * *$ & $-0.438 * *$ & $0.422 * *$ & -0.021 & $-0.264 * *$ & $0.428 * *$ & $0.501 * *$ & 1.000 & & \\
\hline Cause perception $(\mathrm{CP})$ & $0.214^{* *}$ & $-0.364 * *$ & $0.360 * *$ & 0.056 & $-0.257 * *$ & $0.370 * *$ & $0.342 * *$ & $0.537 * *$ & 1.000 & \\
\hline $\begin{array}{l}\text { Response behavior ability perception } \\
\text { (RBAP) }\end{array}$ & $0.132 * *$ & $-0.229 * *$ & $0.184 * *$ & 0.019 & $-0.111 * *$ & $0.235 * *$ & $0.159 * *$ & $0.260 * *$ & $0.310 * *$ & 1.000 \\
\hline Pro-environmental behavior (PEB) & $0.296 * *$ & $-0.468 * *$ & $0.431 * *$ & -0.036 & $-0.321 * *$ & $0.568 * *$ & $0.514 * *$ & $0.637 * *$ & $0.507 * *$ & $0.266 * * 1.000$ \\
\hline
\end{tabular}

Notes. *p < 0.1;** $\mathrm{p}<0.05 ; * * * \mathrm{p}<0.001$ 


\subsection{Research hypothesis testing and effect analysis}

We used Structural Equation Model (SEM) and adopted AMOS17.0 to test the model and the data. As can be seen from the test results, $\chi_{2} / \mathrm{df}$ (3.090) is less than 4; RMSEA (0.064) is less than 0.08; and NFI (0.901), RFI (0.867), IFI (0.931), TLI

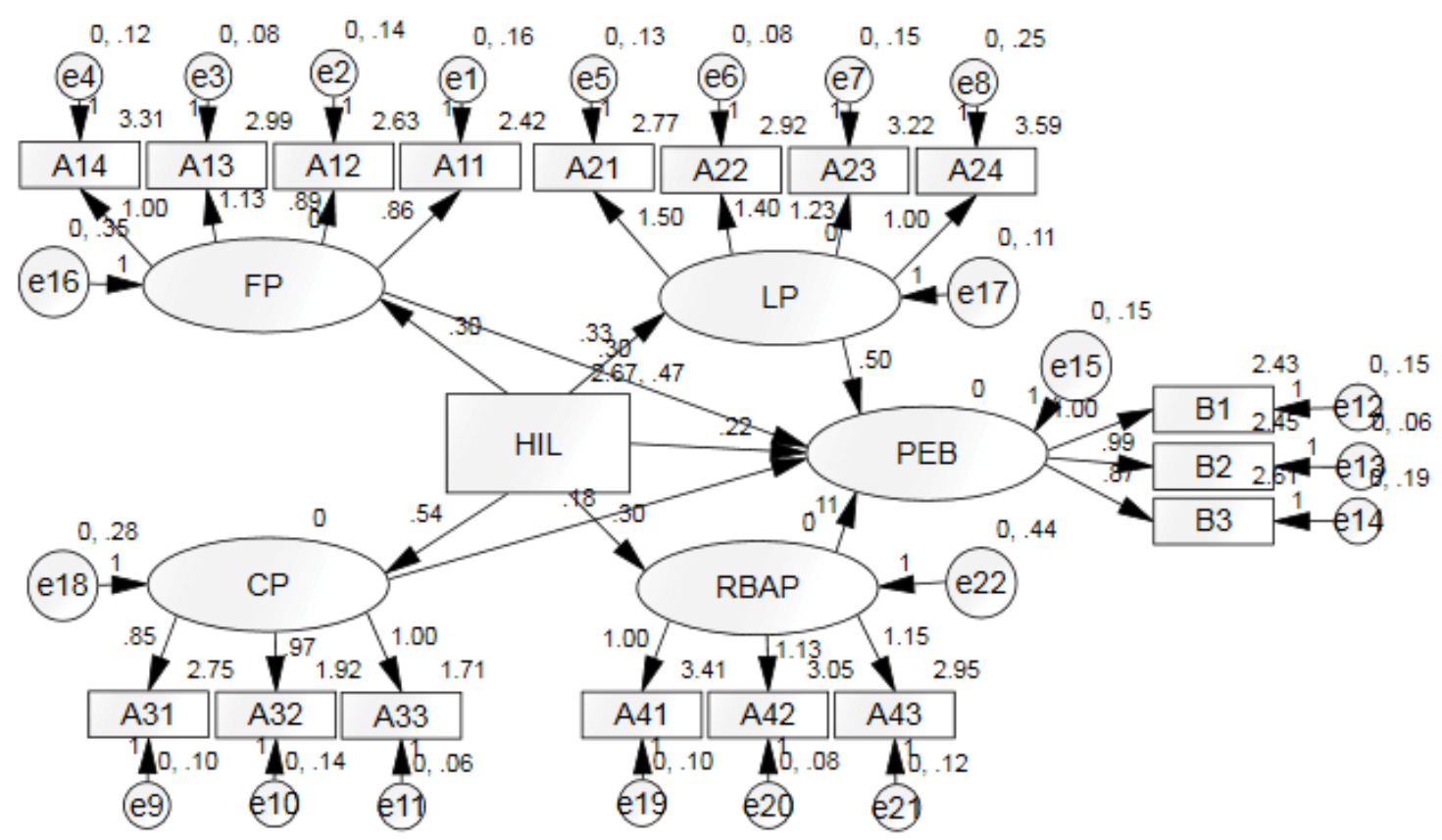

(0.906) and CFI (0.930) are all close to or greater than 0.9. Thus, each index reaches the corresponding standard value, indicating that the model has goodness of fit.

Fig. 2. SEM path analysis model

(1) Direct effect test

The SEM path diagram is shown in Figure 2. According to the SEM estimation, the hypothesis test results are shown in Table 4. It can be seen that the standardized path coefficients for the effects of fact perception, loss perception, cause perception and response behavior ability perception of soil pollution risk with respect to pro-environment behaviors are $0.285(\mathrm{P}<0.001), 0.600(\mathrm{P}<0.001), 0.270(\mathrm{P}<0.001)$ and $0.125(\mathrm{P}<0.05)$. Therefore, hypotheses $1 \mathrm{a}, 1 \mathrm{~b}, 1 \mathrm{c}$ and $1 \mathrm{~d}$ are supported.

Table 4. Path coefficients and hypothesis testing results

\begin{tabular}{ccccc}
\hline \hline Assumed path & Standardization coefficient & S.E. & C.R. & Result \\
\hline H1a: $\mathrm{FP} \rightarrow$ PEB & $0.285^{* * *}$ & 0.061 & 4.701 & Support \\
H1b: $\mathrm{LP} \rightarrow$ PEB & $0.600^{* * *}$ & 0.121 & 4.939 & Support \\
H1c: $\mathrm{CP} \rightarrow$ PEB & $0.270^{* * *}$ & 0.066 & 4.079 & Support \\
H1d: $\mathrm{BBAP} \rightarrow$ PEB & $0.125^{* *}$ & 0.047 & 2.663 & Support \\
\hline
\end{tabular}

Notes. $* \mathrm{p}<0.1 ; * * \mathrm{p}<0.05 ; * * * \mathrm{p}<0.001$ 
(2) Moderating effect test

To test the moderating effects of the household income level, we used the hierarchical regression analysis method. To avoid multi-layer collinearity among variables before regression, we first centralized the data.

First, Model 1: Control variables such as gender, age, education level, family population, per capita production scale and the dependent variable (i.e., farmer's pro-environment behavior) enter the regression equation.

Second, Model 2: On the basis of Model 1, we put independent variables such as fact perception, loss perception, cause perception and response behavior ability perception of soil pollution risk into the regression equation. The coefficients are all positive: $0.224(\mathrm{P}<0.001), 0.331(\mathrm{P}<0.001), 0.225(\mathrm{P}<0.001)$ and $0.088(\mathrm{P}<0.1)$, respectively. Hypotheses 1a, 1b, 1c and 1d are supported again.

Third, Model 3: On the basis of Model 1 and Model 2, we put the moderating variable (i.e., family income level) into the regression equation, and the coefficient is $0.242(\mathrm{P}<0.001)$.

Finally, model 4: On the basis of the first three models, in Model 4 we put the interaction terms of the independent variables and the moderating variable into the regression equation. The significant difference of the two $R^{2}$ and/or the significance of the interaction term coefficients are observed to determine whether there is a moderating effect.

As shown in Table 5, the standardized coefficients of interaction terms between farmers' soil pollution risk fact perception, loss perception, cause perception and household income level are $0.220(\mathrm{P}<0.05), 0.226(\mathrm{P}<0.05)$ and $0.138(\mathrm{P}<0.1)$, respectively. All these values are positive, with significant changes in $R^{2}$. $\mathrm{H} 2 \mathrm{a}, \mathrm{H} 2 \mathrm{~b}$ and $\mathrm{H} 2 \mathrm{c}$ are supported. However, the standardized coefficient of the interaction between response behavior ability perception and household income level is - 0.039 and not statistically significant, which suggests that $\mathrm{H} 2 \mathrm{~d}$ is not supported. 
Table 5. Hierarchical regression analysis results of farmers' PEB

\begin{tabular}{|c|c|c|c|c|}
\hline \multirow[t]{2}{*}{ Independent variables } & \multicolumn{4}{|c|}{ Farmers' PEB } \\
\hline & Model 1 & Model 2 & Model 3 & Model 4 \\
\hline Gender & $0.213 * *$ & 0.086 & 0.037 & -0.001 \\
\hline Age & $-0.218 * *$ & $-0.109 *$ & -0.105 & -0.075 \\
\hline Education & $0.165 * * *$ & 0.037 & 0.037 & 0.026 \\
\hline $\begin{array}{l}\text { Household per capita production } \\
\text { scale }\end{array}$ & -0.044 & -0.043 & -0.032 & -0.039 \\
\hline Family population & -0.054 & -0.011 & -0.003 & 0.007 \\
\hline FP & & $0.224 * * *$ & $0.237 * * *$ & $0.244 * * *$ \\
\hline LP & & $0.331 * * *$ & $0.255^{* * *}$ & $0.329 * * *$ \\
\hline $\mathrm{CP}$ & & $0.225 * * *$ & $0.142 *$ & 0.113 \\
\hline RBAP & & $0.088^{*}$ & $0.075^{*}$ & 0.063 \\
\hline HIL & & & $0.242 * * *$ & $0.407 * * *$ \\
\hline $\mathrm{FP} * \mathrm{HIL}$ & & & & $0.220 * *$ \\
\hline $\mathrm{LP} * \mathrm{HIL}$ & & & & $0.226 * *$ \\
\hline $\mathrm{CP} * \mathrm{HIL}$ & & & & $0.138^{*}$ \\
\hline $\mathrm{RBAP} * \mathrm{HIL}$ & & & & -0.039 \\
\hline$R^{2}$ & 0.341 & 0.597 & 0.636 & 0.682 \\
\hline Adjust $R^{2}$ & 0.328 & 0.583 & 0.621 & 0.664 \\
\hline $\mathrm{F}$ & $26.050 * * *$ & $40.843 * * *$ & $43.156 * * *$ & $37.239 * * *$ \\
\hline
\end{tabular}

Notes. $* \mathrm{p}<0.1 ; * * \mathrm{p}<0.05 ; * * * \mathrm{p}<0.001$

To further explore the moderating effect of household income level, we used the methods of Aiken et al. (1991) to test the regression coefficients of the moderating variable in the high group and the low group. Figure 3 shows the influence model of the interaction terms of soil pollution risk fact perception, loss perception, cause perception, response behavior ability perception and household income level on farmers' PEB. The mean plus 1 standard deviation of the household income level factor is considered to be the high group, and the mean minus 1 standard deviation is considered to be the low group. The regression equations are as follows:

$$
\begin{array}{ll}
Y_{\text {High }}=0.3726 \mathrm{X}+2.991 & Y_{\text {Low }}=0.0762 \mathrm{X}+3.0102 \\
Y_{\text {High }}=0.7091 \mathrm{X}+1.2609 & Y_{\text {Low }}=0.1135 \mathrm{X}+2.8584 \\
Y_{\text {High }}=0.6196 \mathrm{X}+1.8573 & Y_{\text {Low }}=0.2555 \mathrm{X}+2.6438 \\
Y_{\text {High }}=0.1107 \mathrm{X}+3.8087 & Y_{\text {Low }}=-0.0173 \mathrm{X}+3.3423
\end{array}
$$

The first three lines of equations show the relationships between the interaction terms of household income level and soil pollution risk fact perception, loss perception and cause perception and farmers' PEB. In these equations, the slopes are positive. The slopes of the high group are significantly higher than the slopes of the low group, indicating that household income level enhances soil pollution risk. These results 
further support hypotheses $2 \mathrm{a}, 2 \mathrm{~b}$ and $2 \mathrm{c}$.

The fourth line of equations shows the relationship between the interaction term of family income level and response behavior ability perception and farmers' PEB. In the two equations, the slope of the high group is positive and the slope of the low group turns negative; these results further refute hypothesis $2 \mathrm{~d}$.

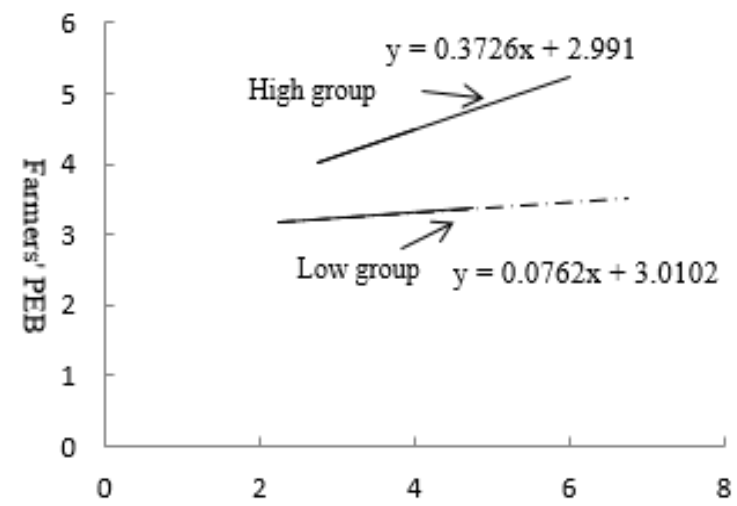

(a) Fact perception of soil pollution risk

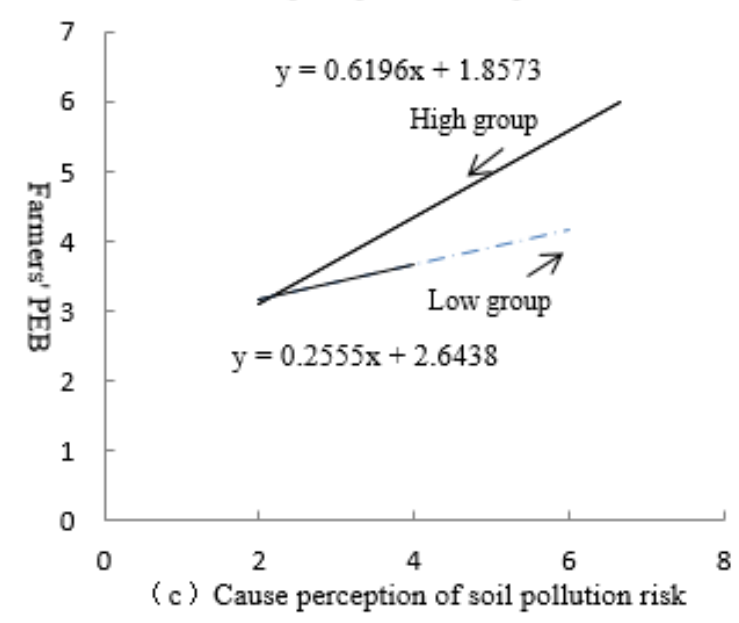

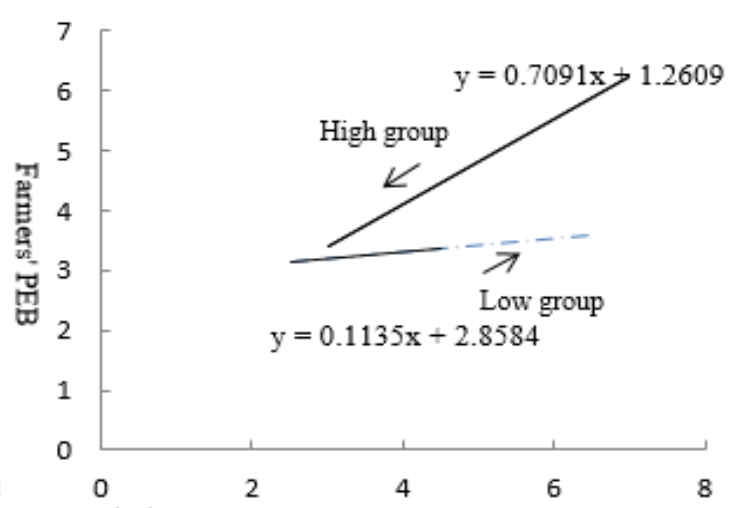

(b) Loss perception of soil pollution risk

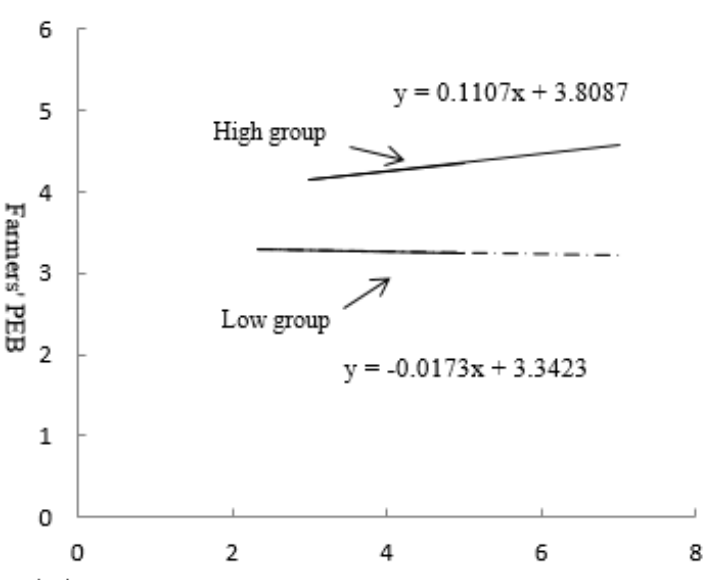

(d) Response behavior ability perception of soil pollution risk

Fig. 3. The moderating effect of household income

\section{Discussion}

From the perspective of Chinese farmers, we explore the relationships between four dimensions their soil pollution risk perception and their PEB, as well as the moderating effect of household income level on these relationships. The research yields several results. (1) Compared with men, women are more inclined to engage in PEB, which is consistent with the findings of Burton (2014), Glass et al. (2016), Malmström et al. (2018), Vicente-Molina et al. (2018) and Tian et al. (2019). All 
these studies found that women are more inclined to avoid environmental risks and pay more attention to the relationship between environmental hazards and personal happiness. However, age is positively correlated with PEB, which is completely contrary to the finding of Melo et al. (2018). This difference may be related to the characteristics of Chinese education. Modern education in China started later than in European countries. The age of farmers is negatively correlated with their educational level, and the educational level of younger farmers is significantly higher than that of older farmers. Educational background is positively correlated with PEB, which is consistent with the findings of Meyer et al. (2015) and Diendéré et al. (2018), who held the view that education enables individuals to consider the marginal cost and benefit of PEB and recognize the causes of environmental problems and their direct impact on their lives, thus encouraging PEB.

From the test results of hypotheses $1 \mathrm{a}, 1 \mathrm{~b}, 1 \mathrm{c}$ and $1 \mathrm{~d}$, it can be seen that the four dimensions of soil pollution risk perception have significant positive impacts on PEB, which indicates that farmers' understanding of the current environmental situation and their awareness of the harms of soil pollution are important factors that promote farmers' PEB. This is consistent with the views of Grasmuck et al. (2005) and Vandermoere et al. (2008). However, the perception of farmers' response behavior ability has a limited impact on their PEB. This further reflects that, unlike farmers in developed countries, Chinese farmers are excessively financially dependent on land. They may feel that they do not have enough funds and ability to avoid environmental pollution, and thus the relationship between response behavior ability perception and PEB is weak. Therefore, it is necessary to strengthen the Chinese educational system and distribute agricultural subsidies to improve farmers' perception of their own response ability in relation to soil pollution.

From the test results of hypotheses $2 \mathrm{a}, 2 \mathrm{~b}$ and $2 \mathrm{c}$, it can be seen that farmers' family income level plays a positive moderating role on the relationships between farmers' soil pollution fact perception, loss perception, cause perception and their PEB, which is similar to the empirical findings of Berthe et al. (2015) on the macro level. However, it is not consistent with the research results of Knight et al. (2012), Lo (2014) and others in developed countries, indicating farmers in China as a developing country have a strong dependence on soil. This further shows that in terms of soil pollution control, the Chinese government needs to effectively protect farmers' interests, promote industrial transformation and upgrading, optimize the allocation of 
rural resources and reduce farmers' dependence on land, so as to enhance their risk perception of soil pollution and promote their PEB. Hypothesis $2 \mathrm{~d}$ has not been supported. It is also found in the survey that most farmers lack an objective understanding of their participation in soil management, and the income of Chinese farmers is generally low. Thus, the impact of Chinese farmers' household income on the relationship between their response behavior ability perception and PEB is limited. This finding heightens the importance to enhance farmers' self-awareness, clarify their role in soil protection, and teach them about the feasibility and necessity of taking practical protective measures. It is also necessary to give appropriate environmental protection subsidies to farmers, encouraging them to protect the environment.

Our empirical findings have important policy implications for soil pollution management and governance. As soil pollution becomes more serious, people's environmental awareness is awakened, and farmers should actively participate in China's "Clean Land War" to enhance their own awareness of soil pollution risks and promote farmers' environment-friendly behavior. The Chinese government also needs to take effective measures to protect farmers' interests through industrial transformation and subsidies for agricultural materials. It is also necessary to strengthen farmers' knowledge about environmental protection, which will encourage them to consciously participate in rectifying the rural living environment and improving their quality of life. Additionally, other emerging countries where farmers' income levels are relatively low can learn from the Chinese experience - enhancing farmers' soil pollution risk through government-directed schemes.

\section{Conclusions}

The contributions of this research are reflected in the following aspects. (1) We introduced the concept of risk perception into the process of soil protection, developed a set of soil pollution risk perception scales, and contributed to social risk perception research. (2) Based on the Protection Motivation Theory, we examined the impact of Chinese farmers' soil pollution risk perception on their PEB and extended the research on the factors affecting farmers' PEB. (3) Based on the Theory of Reasoned Action (TRA) and the Environmental Kuznets Curve (EKC) theory, we examined the moderating role of household income level in the relationship between Chinese farmers' soil pollution risk perception and their PEB, revealing the important role of economic drivers at the micro level. 
However, due to various restrictions, it is inevitable that there are some limitations in this study, which are mainly reflected in the following aspects. First, the cross-sectional nature of questionnaire surveys cannot reveal the time effect on farmers' soil pollution risk perception. Therefore, future research can increase the time period for data collection to enhance the robustness of the findings. Second, we combed the relevant literature and summarized and developed the concept of a soil pollution risk perception scale; however, its universality has yet to be verified.

\section{Acknowledgements}

The authors would like to thank all those who have helped with the research. This research was supported by the National Social Science Fund of China (18BJY085), the Think Tank Special Project of Hunan Social Science Foundation (18ZWB22), and the Project of Social Science Achievement Evaluation Committee of Hunan Province. Any remaining errors are the authors' own. 


\section{References}

Abulizi, A, Yang, Y, Mamat, Z, Luo, J, Abdulslam, D, Xu, Z, Zayiti, A, Ahat, A, Halik, W, 2017. Land-use change and its effects in Charchan Oasis, Xinjiang, China. Land Degrad Dev 28(1):106-115.

Aiken, L S, West, S G, Reno, R R, 1991. Multiple regression: Testing and interpreting interactionsSage.

Ajzen, I, Fishbein, M, 1980. Understanding attitudes and predicting social behaviour.

Armitage, C J, Conner, M, 2001. Efficacy of the theory of planned behaviour: A meta-analytic review. Brit J Soc Psychol 40(4):471-499.

Aydogdu, M, Yenigün, K, 2016. Farmers' risk perception towards climate change: a case of the GAP-Şanliurfa Region, Turkey. Sustainability-Basel 8(8):806.

Azhar, A, Yang, K, 2019. Workplace and Non-workplace Pro-environmental Behaviors: Empirical Evidence from Florida City Governments. Public Admin $\operatorname{Rev}$ 79(3):399-410.

Barreiro-Hurlé, J, Espinosa-Goded, M, Dupraz, P, 2010. Does intensity of change matter? Factors affecting adoption of agri-environmental schemes in Spain. $J$ Environ Plann Man 53(7):891-905.

Bell, A, Parkhurst, G, Droppelmann, K, Benton, T G, 2016. Scaling up pro-environmental agricultural practice using agglomeration payments: Proof of concept from an agent-based model. Ecol Econ 126:32-41.

Berthe, A, Elie, L, 2015. Mechanisms explaining the impact of economic inequality on environmental deterioration. Ecol Econ 116:191-200.

Bockarjova, M, Steg, L, 2014. Can Protection Motivation Theory predict pro-environmental behavior? Explaining the adoption of electric vehicles in the Netherlands. Global environmental change 28:276-288.

Boss, S, Galletta, D, Lowry, P B, Moody, G D, Polak, P, 2015. What do systems users have to fear? Using fear appeals to engender threats and fear that motivate protective security behaviors. MIS Quarterly (MISQ) 39(4):837-864.

Bubeck, P, Wouter Botzen, W J, Laudan, J, Aerts, J C, Thieken, A H, 2018. Insights into flood-coping appraisals of protection motivation theory: Empirical evidence from Germany and France. Risk Anal 38(6):1239-1257.

Burton, R J, 2014. The influence of farmer demographic characteristics on environmental behaviour: A review. J Environ Manage 135:19-26.

Chen, I J, Paulraj, A, 2004. Towards a theory of supply chain management: the 
constructs and measurements. J Oper Manag 22(2):119-150.

Chen, R, De Sherbinin, A, Ye, C, Shi, G, 2014. China's soil pollution: farms on the frontline. Science 344(6185):691.

Collado, S, Staats, H, Sancho, P, 2019. Normative Influences on Adolescents' self-reported pro-environmental behaviors: The role of parents and friends. Environ Behav 51(3):288-314.

De Groot, J I, 2018. Environmental psychology: An introductionJohn Wiley \& Sons.

Delang, C O, 2017. China's Soil Pollution and Degradation ProblemsRoutledge.

Diendéré, A, Nguyen, G, Del Corso, J, Kephaliacos, C, 2018. Modeling the Relationship Between Pesticide Use and Farmers' Beliefs about Water Pollution in Burkina Faso. Ecol Econ 151:114-121.

Dinda, S, 2004. Environmental Kuznets curve hypothesis: a survey. Ecol Econ 49(4):431-455

Estévez, R A, Anderson, C B, Pizarro, J C, Burgman, M A, 2015. Clarifying values, risk perceptions, and attitudes to resolve or avoid social conflicts in invasive species management. Conserv Biol 29(1):19-30.

Farrow, K, Grolleau, G, Ibanez, L, 2017. Social norms and pro-environmental behavior: A review of the evidence. Ecol Econ 140:1-13.

Filis, P, Walker, N, Robertson, L, Eaton-Turner, E, Ramona, L, Bellingham, M, Amezaga, M R, Zhang, Z, Mandon-Pepin, B, Evans, N P, 2019. Long-term exposure to chemicals in sewage sludge fertilizer alters liver lipid content in females and cancer marker expression in males. Environ Int 124:98-108.

Franzen, A, 2003. Environmental attitudes in international comparison: An analysis of the ISSP surveys 1993 and 2000. Soc Sci Quart 84(2):297-308.

Franzen, A, Vogl, D, 2013. Two decades of measuring environmental attitudes: A comparative analysis of 33 countries. Global Environmental Change 23(5):1001-1008.

Frondel, M, Simora, M, Sommer, S, 2017. Risk Perception of Climate Change: Empirical Evidence for Germany. Ecol Econ 137:173-183.

Gattig, A, Hendrickx, L, 2007. Judgmental discounting and environmental risk perception: Dimensional similarities, domain differences, and implications for sustainability. J Soc Issues 63(1):21-39.

Glass, C, Cook, A, Ingersoll, A R, 2016. Do women leaders promote sustainability? Analyzing the effect of corporate governance composition on environmental 
performance. Bus Strateg Environ 25(7):495-511.

Götz, K, Courtier, A, Stein, M, Strelau, L, Sunderer, G, Vidaurre, R, Winker, M, Roig, B, 2019. Risk Perception of Pharmaceutical Residues in the Aquatic Environment and Precautionary Measures, Management of Emerging Public Health Issues and RisksElsevier, pp. 189-224.

Grasmück, D, Scholz, R W, 2005. Risk perception of heavy metal soil contamination by high-exposed and low-exposed inhabitants: The role of knowledge and emotional concerns. Risk Analysis: An International Journal 25(3):611-622.

Grossman, G M, Krueger, A B, 1991. Environmental impacts of a North American free trade agreement, National Bureau of Economic Research.

Grossman, G M, Krueger, A B, 1995. Economic growth and the environment. The quarterly journal of economics 110(2):353-377.

Gunier, R B, Kang, A, Hammond, S K, Reinier, K, Lea, C S, Chang, J S, Does, M, Scelo, G, Kirsch, J, Crouse, V, 2017. A task-based assessment of parental occupational exposure to pesticides and childhood acute lymphoblastic leukemia. Environ Res 156:57-62.

Hagger, M S, Chatzisarantis, N L, Biddle, S J, 2002. A meta-analytic review of the theories of reasoned action and planned behavior in physical activity: Predictive validity and the contribution of additional variables. Journal of sport and exercise psychology 24(1):3-32.

Han, H, 2015a. Travelers' pro-environmental behavior in a green lodging context: Converging value-belief-norm theory and the theory of planned behavior. Tourism Manage 47:164-177.

Han, H, 2015b. Travelers' pro-environmental behavior in a green lodging context: Converging value-belief-norm theory and the theory of planned behavior. Tourism Manage 47:164-177.

Hodge, I, 2013. Agri-environment policy in an era of lower government expenditure: CAP reform and conservation payments. J Environ Plann Man 56(2):254-270.

Hou, D, Li, F, 2017. Complexities surrounding China's soil action plan. Land Degrad Dev 28(7):2315-2320.

Huang, X, Huang, X, He, Y, Yang, X, 2017. Assessment of livelihood vulnerability of land-lost farmers in urban fringes: A case study of Xi'an, China. Habitat Int 59:1-9.

Inglehart, R, 2018. Culture shift in advanced industrial societyPrinceton University 
Press.

Janmaimool, P, 2017. Application of protection motivation theory to investigate sustainable waste management behaviors. Sustainability-Basel 9(7):1079.

Jia, H, 2018. Green Travel Behavior in Urban China: Influencing Factors and their Effects. Sustain Dev 26(4):350-364.

Jorgenson, A, Schor, J, Huang, X, 2017. Income inequality and carbon emissions in the United States: a state-level analysis, 1997-2012. Ecol Econ 134:40-48.

Katz, D, 2015. Water use and economic growth: reconsidering the environmental Kuznets curve relationship. J Clean Prod 88:205-213.

Kim, S, Jeong, S, Hwang, Y, 2013. Predictors of pro-environmental behaviors of American and Korean students: The application of the theory of reasoned action and protection motivation theory. Sci Commun 35(2):168-188.

Knight, K W, Messer, B L, 2012. Environmental concern in cross - national perspective: the effects of affluence, environmental degradation, and World Society. Soc Sci Quart 93(2):521-537.

Lacroix, K, Gifford, R, 2018. Psychological barriers to energy conservation behavior: The role of worldviews and climate change risk perception. Environ Behav 50(7):749-780.

Lange, F, Dewitte, S, 2019. Measuring pro-environmental behavior: Review and recommendations. J Environ Psychol.

Langford, I H, Marris, C, McDonald, A, Goldstein, H, Rasbash, J, O'Riordan, T, 1999. Simultaneous analysis of individual and aggregate responses in psychometric data using multilevel modeling. Risk Anal 19(4):675-683.

Lastra-Bravo, X B, Hubbard, C, Garrod, G, Tolón-Becerra, A, 2015. What drives farmers' participation in EU agri-environmental schemes?: Results from a qualitative meta-analysis. Environ Sci Policy 54:1-9.

Li, W, Liu, J, Li, D, 2012. Getting their voices heard: Three cases of public participation in environmental protection in China. J Environ Manage 98:65-72.

Liu, K, Huisingh, D, Zhu, J, Ma, Y, O'Connor, D, Hou, D, 2018. Farmers' perceptions and adaptation behaviours concerning land degradation: A theoretical framework and a case-study in the Qinghai-Tibetan Plateau of China. Land Degrad Dev 29(8):2460-2471.

Lo, A Y, 2014. Negative income effect on perception of long-term environmental risk. Ecol Econ 107:51-58. 
Lu, Y, Song, S, Wang, R, Liu, Z, Meng, J, Sweetman, A J, Jenkins, A, Ferrier, R C, Li, H, Luo, W, 2015. Impacts of soil and water pollution on food safety and health risks in China. Environ Int 77:5-15.

Maddux, J E, Rogers, R W, 1983. Protection motivation and self-efficacy: A revised theory of fear appeals and attitude change. J Exp Soc Psychol 19(5):469-479.

Malawska, A, Topping, C J, 2016. Evaluating the role of behavioral factors and practical constraints in the performance of an agent-based model of farmer decision making. Agr Syst 143:136-146.

Malmström, M, Voitkane, A, Johansson, J, Wincent, J, 2018. VC Stereotypes About Men and Women Aren't Supported by Performance Data. Harvard Bus Rev.

Marcon, A, Nguyen, G, Rava, M, Braggion, M, Grassi, M, Zanolin, M E, 2015. A score for measuring health risk perception in environmental surveys. Sci Total Environ 527:270-278.

Marr, E J, Howley, P, 2019. The accidental environmentalists: Factors affecting farmers' adoption of pro-environmental activities in England and Ontario. J Rural Stud.

Melo, P C, Ge, J, Craig, T, Brewer, M J, Thronicker, I, 2018. Does work-life balance affect pro-environmental behaviour? Evidence for the UK using longitudinal microdata. Ecol Econ 145:170-181.

Mertens, K, Jacobs, L, Maes, J, Poesen, J, Kervyn, M, Vranken, L, 2018. Disaster risk reduction among households exposed to landslide hazard: A crucial role for self-efficacy? Land Use Policy 75:77-91.

Meyer, A, 2015. Does education increase pro-environmental behavior? Evidence from Europe. Ecol Econ 116:108-121.

Mills, J, Gaskell, P, Ingram, J, Dwyer, J, Reed, M, Short, C, 2017. Engaging farmers in environmental management through a better understanding of behaviour. Agr Hum Values 34(2):283-299.

Morren, M, Grinstein, A, 2016. Explaining environmental behavior across borders: A meta-analysis. J Environ Psychol 47:91-106.

Morris, W, Henley, A, Dowell, D, 2017. Farm diversification, entrepreneurship and technology adoption: Analysis of upland farmers in Wales. J Rural Stud $53: 132-143$.

Orbell, S, Hodgkins, S, Sheeran, P, 1997. Implementation intentions and the theory of planned behavior. Pers Soc Psychol B 23(9):945-954. 
Özkara, A, Aky1l, D, Konuk, M, 2016. Pesticides, environmental pollution, and health, Environmental Health Risk-Hazardous Factors to Living SpeciesIntechOpen.

Paço, A, Lavrador, T, 2017. Environmental knowledge and attitudes and behaviours towards energy consumption. J Environ Manage 197:384-392.

Paillé, P, Mejía-Morelos, J H, Marché-Paillé, A, Chen, C C, Chen, Y, 2016. Corporate greening, exchange process among co-workers, and ethics of care: An empirical study on the determinants of pro-environmental behaviors at coworkers-level. $J$ Bus Ethics 136(3):655-673.

Ponce, P, Alvarado, R, Ponce, K, Alvarado, R, Granda, D, Yaguana, K, 2019. Green returns of labor income and human capital: Empirical evidence of the environmental behavior of households in developing countries. Ecol Econ 160:105-113.

Qi, X, Wang, R Y, Li, J, Zhang, T, Liu, L, He, Y, 2018. Ensuring food security with lower environmental costs under intensive agricultural land use patterns: A case study from China. J Environ Manage 213:329-340.

Rehman, T, McKemey, K, Yates, C M, Cooke, R J, Garforth, C J, Tranter, R B, Park, J R, Dorward, P T, 2007. Identifying and understanding factors influencing the uptake of new technologies on dairy farms in SW England using the theory of reasoned action. Agr Syst 94(2):281-293.

Renn, O, 2017. Risk governance: coping with uncertainty in a complex worldRoutledge.

Rogers, R W, 1975. A protection motivation theory of fear appeals and attitude change1. The Journal of psychology 91(1):93-114.

Sankoh, A I, Whittle, R, Semple, K T, Jones, K C, Sweetman, A J, 2016. An assessment of the impacts of pesticide use on the environment and health of rice farmers in Sierra Leone. Environ Int 94:458-466.

Schmitt, M T, Aknin, L B, Axsen, J, Shwom, R L, 2018. Unpacking the relationships between pro-environmental behavior, life satisfaction, and perceived ecological threat. Ecol Econ 143:130-140.

Shao, S, Tian, Z, Fan, M, 2018. Do the rich have stronger willingness to pay for environmental protection? New evidence from a survey in China. World Dev 105:83-94.

Shiva, V, 2016. The violence of the green revolution: Third world agriculture, ecology, and politicsUniversity Press of Kentucky. 
Singh, S, Kumar, B, Sharma, N, Rathore, K S, 2019. Organic Farming: Challenge for Chemical Pollution in Aquatic Ecosystem, Handbook of Research on the Adverse Effects of Pesticide Pollution in Aquatic EcosystemsIGI Global, pp. 408-420.

Slovic, P, 1987. Perception of risk. Science 236(4799):280-285.

Slovic, P, 2016. The perception of riskRoutledge.

Smith, E K, Mayer, A, 2018. A social trap for the climate? Collective action, trust and climate change risk perception in 35 countries. Global Environmental Change 49:140-153.

Steg, L, Vlek, C, 2009. Encouraging pro-environmental behaviour: An integrative review and research agenda. J Environ Psychol 29(3):309-317.

Stern, P C, 2000. New environmental theories: toward a coherent theory of environmentally significant behavior. J Soc Issues 56(3):407-424.

Struik, P C, Kuyper, T W, 2017. Sustainable intensification in agriculture: the richer shade of green. A review. Agron Sustain Dev 37(5):39.

Sullivan-Wiley, K A, Gianotti, A G S, 2017. Risk perception in a multi-hazard environment. World Dev 97:138-152.

Sun, C, Zhu, X, 2014. Evaluating the public perceptions of nuclear power in China: Evidence from a contingent valuation survey. Energ Policy 69:397-405.

Sun, H, Teh, P L, Linton, J D, 2018. Impact of environmental knowledge and product quality on student attitude toward products with recycled/remanufactured content: Implications for environmental education and green manufacturing. Bus Strateg Environ 27(7):935-945.

Sun, X, Hu, Z, Li, M, Liu, L, Xie, Z, Li, S, Wang, G, Liu, F, 2019. Optimization of pollutant reduction system for controlling agricultural non-point-source pollution based on grey relational analysis combined with analytic hierarchy process. $J$ Environ Manage 243:370-380.

Sun, Y, Li, H, Guo, G, Semple, K T, Jones, K C, 2019. Soil contamination in China: Current priorities, defining background levels and standards for heavy metals. J Environ Manage 251:109512

Thompson, P B, 2017. The spirit of the soil: Agriculture and environmental ethicsRoutledge.

Tian, Q, Robertson, J L, 2019. How and when does perceived CSR affect employees' engagement in voluntary pro-environmental behavior? $J$ Bus Ethics 155(2):399-412. 
Toma, L, Mathijs, E, 2007. Environmental risk perception, environmental concern and propensity to participate in organic farming programmes. J Environ Manage 83(2):145-157.

Van Maele-Fabry, G, Gamet-Payrastre, L, Lison, D, 2017. Residential exposure to pesticides as risk factor for childhood and young adult brain tumors: A systematic review and meta-analysis. Environ Int 106:69-90.

Vandermoere, F, 2008. Hazard perception, risk perception, and the need for decontamination by residents exposed to soil pollution: the role of sustainability and the limits of expert knowledge. Risk Analysis: An International Journal 28(2):387-398.

Vicente-Molina, M A, Fernández-Sainz, A, Izagirre-Olaizola, J, 2018. Does gender make a difference in pro-environmental behavior? The case of the Basque Country University students. J Clean Prod 176:89-98.

Wachinger, G, Renn, O, Begg, C, Kuhlicke, C, 2013. The risk perception paradox-implications for governance and communication of natural hazards. Risk Anal 33(6):1049-1065.

Wang, Y, Liang, J, Yang, J, Ma, X, Li, X, Wu, J, Yang, G, Ren, G, Feng, Y, 2019. Analysis of the environmental behavior of farmers for non-point source pollution control and management: An integration of the theory of planned behavior and the protection motivation theory. J Environ Manage 237:15-23.

Weber, O, Scholz, R W, Bühlmann, R, Grasmück, D, 2001. Risk perception of heavy metal soil contamination and attitudes toward decontamination strategies. Risk Anal 21(5):967.

Wu, H, Ge, Y, 2019. Excessive Application of Fertilizer, Agricultural Non-Point Source Pollution, and Farmers' Policy Choice. Sustainability-Basel 11(4):1165.

Xu, D, Peng, L, Liu, S, Su, C, Wang, X, Chen, T, 2017. Influences of migrant work income on the poverty vulnerability disaster threatened area: A case study of the Three Gorges Reservoir area, China. Int J Disast Risk Re 22:62-70.

Yang, Q, Li, Z, Lu, X, Duan, Q, Huang, L, Bi, J, 2018. A review of soil heavy metal pollution from industrial and agricultural regions in China: Pollution and risk assessment. Sci Total Environ 642:690-700.

Zhang, W, Liu, M, Hubacek, K, Feng, K, Wu, W, Liu, Y, Jiang, H, Bi, J, Wang, J, 2019. Virtual flows of aquatic heavy metal emissions and associated risk in China. J Environ Manage 249:109400. 
Zhao, C, Zhang, M, Wang, W, 2019. Exploring the influence of severe haze pollution on residents' intention to purchase energy-saving appliances. J Clean Prod 212:1536-1543. 